Bryn Mawr College

Scholarship, Research, and Creative Work at Bryn Mawr College

Classical and Near Eastern Archaeology Faculty

Research and Scholarship

Classical and Near Eastern Archaeology

2004

\title{
The Mycenaean Feast: An Introduction
}

James C. Wright

Bryn Mawr College, jwright@brynmawr.edu

Let us know how access to this document benefits you.

Follow this and additional works at: http://repository.brynmawr.edu/arch_pubs

Part of the Classical Archaeology and Art History Commons, and the History of Art, Architecture, and Archaeology Commons

\section{Custom Citation}

Wright, James C. 2004. The Mycenaean Feast: An Introduction. Hesperia 73:121-132.

This paper is posted at Scholarship, Research, and Creative Work at Bryn Mawr College. http://repository.brynmawr.edu/arch_pubs/91

For more information, please contact repository@brynmawr.edu. 
HESPERIA $73(2004)$

Pages $12 I^{-1}{ }^{2} 2$
1. I wish to thank Paul Halstead and Jack Davis for reading a draft of this introduction, providing useful references, and making valuable suggestions.

2. Abstracts of the papers delivered as part of "The Mycenaean Feast: An Archaeological Colloquium" at the AIA Annual Meeting in Philadelphia in 2002 are published in $A J A 106$ (2002), pp. 272-273.

\section{THE MYCENAEAN FEAST} An Introduction

In 2001, I participated in a conference on the culture and cuisine of the prehistoric Aegean, sponsored by the Department of Prehistory and Archaeology at the University at Sheffield. ${ }^{1}$ Many of the papers focused in one way or another on feasting, and I realized that the archaeological remains of feasting were more abundant than I had suspected. Especially interesting was the amount of evidence from different sources that elucidated feasting in Mycenaean society. I decided that it would be worthwhile to organize a conference on that subject, and, initially collaborating with Sharon Stocker, proposed a session entitled "The Mycenaean Feast" for the 103rd Annual Meeting of the Archaeological Institute of America (AIA), to be held in Philadelphia in January 2002. We wished to demonstrate that the archaeological record was sufficiently rich to allow the identification and characterization of the practice of feasting in Mycenaean times. We therefore invited colleagues to contribute papers approaching this issue from a number of perspectives, using several varieties of evidence: iconographic, artifactual, textual, faunal, and contextual (actual deposits). ${ }^{2}$

The papers presented in Philadelphia included one by Jack Davis and Stocker on the evidence from the Palace of Nestor at Pylos; another on a deposit from Tsoungiza by Mary Dabney, Paul Halstead, and Patrick Thomas; one by Lisa Bendall on the textual and archaeological evidence from Pylos; and my own investigation of the problem of identifying feasting from tomb assemblages, as depicted on frescoes, and from other sources. If these papers succeeded in characterizing a distinctive "Mycenaean" practice, that practice could be further defined by contrasting it with those from cultures in contact with the Mycenaeans. Thus, we also invited Elisabetta Borgna to talk about Minoan feasting, with special reference to the evidence from Phaistos, and Louise Steel to discuss feasting in Late Bronze Age Cyprus. Both were charged to consider how practices in their areas were affected by Mycenaean customs of feasting, and to what extent local practices continued or even resisted the introduction of new practices. Robin Hägg served as the respondent and compared and contrasted the Late Bronze Age evidence with later Greek practices of feasting and sacrifice. Afterward, the participants agreed that it would be worthwhile to rework our papers and present them for publication, and Tracey Cullen suggested we consider publishing them as a special issue of Hesperia. 
In the course of pulling this volume together, changes were made. Bendall's paper will appear in the publication of the Sheffield Conference and therefore is not included here. ${ }^{3}$ I invited Thomas Palaima to contribute a paper that treated the Linear B evidence, an exceptionally rich and fundamental source of information. A study of feasting in the Homeric epics and during the Iron Age was needed to round out the subject, and Susan Sherratt accepted the challenge. Together, the authors survey the different kinds of evidence for feasting during the Mycenaean era, set this evidence in the context of feasting practices among interdependent cultures, and consider the difficult issue of a tradition and its transformation as the "civilization" that practiced it becomes only a practice of memory.

Thematic conferences are common in the discipline of Aegean preand protohistory, and have dealt with subjects such as invasions and migrations, ${ }^{4}$ the "Minoan thalassocracy, ${ }^{5}$ death and burial customs, ${ }^{6}$ the state, ${ }^{7}$ warfare, ${ }^{8}$ religion, ${ }^{9}$ urbanism, ${ }^{10}$ and economy and politics ${ }^{11}$ — to name only a few. Fewer have been solely concerned with the Mycenaeans, ${ }^{12}$ and fewer yet have chosen a theme that is a specific social practice. The reason for this may be that archaeologists are not comfortable exploring social practices, which are difficult to document through the material record. For example, if it is difficult for archaeologists to reconstruct religion, even in the abstract, it is more difficult, if not altogether questionable, to try to understand highly social practices such as marriage, kinship, and feasting. That we make the effort to do so today represents the extent to which we have made sufficient advances in our examination of evidence. Addressing these issues has required overcoming skepticism about the limits of archaeological inquiry, ${ }^{13}$ and the development of methods of analysis that move beyond traditional concerns with typology, chronology, and distribution. This renewed interest in recovering social aspects of ancient societies is functional in that it reflects a desire to know how and for what purpose objects were created and employed by humans; it also, however, grows out of our increasing recognition that the issues of production and consumption that have interested us for decades are products of the social agency of individuals and of corporate bodies. ${ }^{14}$

Skeptics of archaeology's ability to explain past events base their concern on the unbridgeable maw that separates the material past from the present. The conceptual gap lies between the material remains of the past and the intentions and actions of humans who created them, and it is argued that it can be bridged through the use of ethnographic and ethnoarchaeological analogy. This argument, however, rests on the assumption that humans acted in the past in much the same manner in which they do today. If archaeology is ever to contribute to our understanding of the past, it is necessary that we employ analogy. In this sense, archaeology, like other interpretive disciplines of the humanities, is a "theoretically informed practice." ${ }^{15}$ Ethnography is fundamental to such an archaeology, but, as Comaroff and Comaroff claim, it must be an ethnography that bears

the imprint of contemporary debates, of assumptions and claims profoundly questioned, of the impossibility of ironic detachment.... [It] must also assert a faith that the human world,
3. Bendall, forthcoming. The papers from this conference will appear in Halstead and Barrett, forthcoming. 4. Crossland and Birchall 1974.

5. Hägg and Marinatos 1984.

6. Laffineur 1987; Hägg and

Nordquist 1990; Branigan 1998.

7. Laffineur and Niemeier 1995.

8. Laffineur 1999a.

9. Hägg and Nordquist 1990;

Laffineur and Hägg 2001.

10. Branigan 2001.

11. Voutsaki and Killen 2001.

12. Shelmerdine and Palaima 1984;

Voutsaki and Killen 2001.

13. Leach 1977; Patrik 1985;

Shanks and Tilley 1987; Hodder 1991.

14. Giddens 1984.

15. Comaroff and Comaroff 1992 , p. $x$. 
post-anything and -everything, remains the product of discernible social and cultural processes: processes partially indeterminate yet, in some measure, systematically determined; ambiguous and polyvalent, yet never utterly incoherent or meaningless; open to multiple constructions and contest, yet never entirely free of order-or the reality of power and constraint. ${ }^{16}$

The authors go on to argue that ethnography "is indispensable to the production of knowledge about all manner of social phenomena. Indeed ... . no humanist account of the past or present can (or does) go very far without the kind of understanding that the ethnographic gaze presupposes." ${ }^{17}$ In the study of feasting, the fundamental value of ethnography is evident in a recent volume edited by Michael Dietler and Brian Hayden on the archaeology and ethnography of feasting; ${ }^{18}$ ethnographic and archaeological accounts from around the globe provide rich and varied examples on which to draw. The articles demonstrate the extent to which some human activities have a universal quality and they also counter simplistic explanations by broadening the choices of probable interpretations, sometimes even offering contradictory ones. ${ }^{19}$

In studying the practice of feasting, archaeologists devise and utilize methods of analysis that lead to a direct assessment of specific human activities. This is most apparent in faunal analysis, in which the comparative, ethnoarchaeological study of butchering now permits declarative assessments of the purposes of different kinds of butchering marks and bone treatment and disposal. ${ }^{20}$ Increasingly, the analysis of residues in vessels allows us to determine, with varying degrees of precision, the contents of vessels and the ways in which vessels were used in food production. ${ }^{21}$ Similarly, studies of deposits can lead to precise histories of deposition, for example through attention to palaeoentomological evidence, the remains of which can indicate the presence of organic waste in which insects thrived during the spring and summer months. ${ }^{22}$

16. Comaroff and Comaroff 1992, p. xi.

17. Comaroff and Comaroff 1992, p. xi.

18. Dietler and Hayden 2001.

19. Orme 1981, p. 284.

20. Binford 1981; Speth 1983;

O'Connor 1998. I thank Paul Halstead

for supplying these references.

21. Tzedakis and Martlew 1999.

22. Pauketat et al. 2002, pp. 261263.

23. Pauketat et al. 2002, pp. 265266.

24. Hamilakis and Konsolaki 2004, p. 142 .

25. Pauketat et al. 2002, pp. 268269; Pappa et al., forthcoming.

26. Tzedakis and Martlew 1999; McGovern et al. 1999; McGovern 2003.
It is also possible to reconstruct from palaeobotanical and zoological remains the very wide range of foodstuffs consumed at feasts. In feasting deposits at Cahokia in southern Illinois, for example, Pauketat and his colleagues found evidence of corn, bottle gourd, squash, sunflower, sumpweed, chenopod, maygrass, erect knotweed, four varieties of nuts, grape, and many fruits (persimmon, strawberry, plum, bramble, elderberry, nightshade, blackhaw, mulberry, sunflower), along with greens and small grains (amaranth, purslane, panicoid grasses, carpetweed, and spurges). ${ }^{23}$ At the Mycenaean sanctuary at Ayios Konstantinos, Hamilakis and Konsolaki identified sheep, goat, cattle, pig, red deer, mouse/rat, rock dove, bird, and fish.$^{24}$ Comparative study of ceramic vessel forms and their quantities in deposits elucidates similarities and differences between feasting deposits and domestic ones, as demonstrated by Pauketat et al. in their analysis of vessels from Cahokia and by Pappa and colleagues in a study of the drinking cups from Makriyalos in Macedonia. ${ }^{25}$ As noted, chemical analysis of contents also promises identification of specific foodstuffs prepared in vessels. ${ }^{26} \mathrm{~A}$ particularly valuable source of information is textual, as observed by Schmandt-Besserat in her review of feasting in the ancient Near East, 
and as is well known from the rich documentation of the deipnon and symposion in ancient Greece. ${ }^{27}$ For the study of Mycenaean feasting, the Linear B texts from Thebes, Pylos, and Knossos have proven especially important. These examples demonstrate the array of information available to archaeologists investigating this fundamental human social practice.

It is perhaps the strength of the textual evidence for the Mycenaean feast that gives the greatest credibility to the collection of papers in this volume. These papers provide a material substance to the bureaucratic shorthand of the texts. The Linear B documents are notations of palace scribes, found in their briefest form on sealings that accompanied groups of texts or objects, ${ }^{28}$ and more fully on the tablets collected in archives. ${ }^{29}$ These records do not contain specific references to "feasts" but rather indicate them indirectly. ${ }^{30}$ Thus, Killen, following on the work of Piteros, Olivier, and Melena, showed how the clay sealings from Thebes that documented the provisioning of animals for sacrifice or slaughter were related to similar documents from Knossos and Pylos. ${ }^{31}$ Taken together, the records provide powerful evidence for large-scale feasts.

In a further study of this subject, Killen associated the well-known Ta series tablets from Pylos with the auditing of feasting equipment in the palace. ${ }^{32}$ These tablets list bronze vessels that had been stored, record their condition, and list other equipment, including tables, chairs, and stools, different kinds of ceramic serving vessels, and axes and knives. Although the interpretation relies on circumstantial associations, it represents a powerful argument for feasting and its importance in activities at the palace, as Palaima's article in this volume demonstrates. The provisioning and preparation for feasts, especially large-scale events sponsored by the palace, had a major impact on many sectors of the economy and society. When one considers the many types of vessels, implements, furnishings, and foodstuffs employed in a feast, and the large number of animals involved, ${ }^{33}$ the magnitude of Mycenaean feasting becomes apparent. Killen suggests this by stating that the importance of the feast was for "holding together the fabric of the society" and he goes on to claim that "the provision of feasts was felt to be one of the duties of the monarch: part of what he gave in reciprocity, as it were, for the services and taxes which the subjects provided him with; and feasts also clearly played an important role in ensuring the continuing good-will of important state officials and of the subordinate nobility." ${ }^{34}$ We may observe in passing that the faunal deposit of a feast at Neolithic Makriyalos may have been so large as to require the slaughter of all the cattle, pigs, and sheep/goats of the entire region, ${ }^{35}$ and Halstead and Isaakidou (see also Stocker and Davis, this volume) estimate

27. Schmandt-Bessarat 2001, pp. 397-399. For deipnon and symposion, see Murray 1990, p. 6; Lissarrague 1990.

28. Piteros, Olivier, and Melena 1990; for general discussion of seals and sealings, see the contributions in Palaima 1990 and Palaima 1984, 1987, 1988, 1996, 2000a, b.
29. For a general introduction to the tablets, see Chadwick 1987, esp. pp. 33-43; also Chadwick 1958; Olivier 1967; Ventris and Chadwick 1973; Palaima 1988; Bennet 2001, pp. 27-33.

30. Compare the discussion of the Homeric term sais in Sherratt's contribution to this volume.
31. Piteros, Olivier, and Melena 1990, pp. 171-184. Killen 1994, pp. 71-76; see also Killen 1992.

32. Killen 1998.

33. Isaakidou et al. 2002; Stocker and Davis, this volume.

34. Killen 1994, p. 70.

35. Pappa et al., forthcoming. 
that the total number of persons fed at a feast at Pylos was "enough, by the rules of thumb of modern British receptions, to feed several thousand guests." ${ }^{36}$ These calculations help us appreciate the widespread impact of feasting on the economy of the Mycenaean palaces, and they also make clear how many areas of scribal activity were affected by feasting.

In this regard Palaima's contribution to this volume marks a significant advance on previous scholarship. He examines the tablets for evidence of the administrative structure of feasting by focusing on the role of individuals, notably the "collectors," in the administration of feasting; by indicating the larger context of feasting within the practice of sacrifice and worship at sanctuaries; and by considering the geographical and political implications posed by the tablets. From his study we learn that feasting was administered in similar fashion by the palaces at Knossos, Pylos, and Thebes; it was part of a highly centralized palace bureaucracy that had firm control of territories and provincial localities up to $100 \mathrm{~km}$ distant; and that state feasting was sponsored not only at the major palaces, but also at secondary centers or localities within them. Monitoring of feasting was also important within the hierarchies of bureaucratic attention. As Palaima notes, feasting was an activity in which the wanax was centrally involved. Furthermore, in his discussion of the Ta series from Pylos, he observes that the inventorying of festal equipment fell under the purview of one of the most important scribes. On the assumption that different sets of texts are closely interrelated, he is able to look at the records of thrones and stools for details of the seating arrangement of high officials.

This textual information supports the interpretation of evidence from Tsoungiza by Dabney, Halstead, and Thomas in this volume. They argue that a feast held at Tsoungiza, a minor settlement in the territory of Mycenae, was connected with the palace or its representatives. Equally, the archaeological evidence from the Palace of Nestor presented here by Stocker and Davis confirms Palaima's textual exegesis. The authors show that the locations of feasting deposits around the palace, especially in the Archives Complex, relate to large-scale feasts sponsored by the state and probably also to the seating of highly ranked individuals.

If the centrality of the feast among the social practices of the Mycenaeans is evident, then we should inquire about the impact of feasting on the structure and organization of the society. The texts focus on feasting that was politically and economically significant enough to be recorded. Feasting, however, surely operated at levels and in areas outside the purview of the palaces. In this regard, the ethnographic study of feasting is particularly helpful. We learn that feasts occur throughout the year. They are performed by every social group - from the family to an entire society - by kin, moiety and sodality, and individuals acting through all kinds of personae. The occasions include any event from birth to death that people choose to celebrate. Clarke's list of occasions for Akha feasts is illustrative: to honor ancestors, mark the naming of a newborn, cure sickness, honor butchers, for workmen as a penalty, for purification, to mark a gate rebuilding, honor the Lords of the Earth, mark the harvest, announce the new year, on occasion of an annual drama, for a wedding, for a new house,

to mark menopause, and on occasion of a funeral. ${ }^{37}$ It is little wonder, in

36. Halstead and Isaakidou, forthcoming; see also Isaakidou et al. 2002. 37. Clarke 2001, p. 153. 
consequence, that the reasons proposed for feasting have been equally varied, with different observers emphasizing different aspects of the feast. ${ }^{38}$ Some have seen feasts as mechanisms for redistribution, others as means for demonstrating heritable holdings and status, while many claim that they demonstrate and amplify prestige. It is evident that feasts were not merely performed for practical and social benefit, but also for theological and liturgical reasons - in order, for example, to maintain the cosmic order. The result, however, as Hayden emphasizes, is practical, ${ }^{39}$ and his list of nine benefits of feasting is a powerful statement about the degree to which this social practice permeates the many dimensions of human activities. ${ }^{40}$ According to Hayden, feasts

1. mobilize labor;

2. create cooperative relationships within groups or, conversely, exclude other groups;

3. create cooperative alliances between social groups (including political support between households);

4. invest surpluses and generate profits;

5. attract desirable mates, labor, allies, or wealth exchanges by advertising the success of the group;

6. create political power (control over resources and labor) through the creation of a network of reciprocal debts;

7. extract surplus produce from the general populace for elite use;

8. solicit favors; and

9. compensate for transgressions.

We are not yet in the position of being able to identify which of the many possible reasons for feasting are those most relevant to Mycenaean society. Killen has argued that, among tablets from Pylos, Ta 711 refers to preparations for a feast upon the appointment of a new magistrate, and Un 138 "records the provisions for a banquet held 'on the initiation of the king' (mu-jo-me-noe-pi wa-na-ka-te, / muiomenôi epi wanaktei/)." ${ }^{41}$ Palaima discusses other tablets that link feasting with the wanax, which is to be expected among the records of the palace, but surely other motivations for feasting occurred, both within the palace and among communities outside it.

In their study of the deposit from the rural settlement at Tsoungiza, Dabney, Halstead, and Thomas suggest that it was from a feast that was a community celebration marking a relationship between the community and the palace, but there is no strong evidence to indicate more precisely the reason for this feast. I had earlier proposed that the deposit at Tsoungiza represented a rural shrine, ${ }^{42}$ but the faunal remains and analysis of the ceramics now strongly suggest a feast with a religious component, which raises a question about the identification of religious centers outside the palaces. ${ }^{43}$ Evidence from the recently excavated shrine complex at Ayios Konstantinos on Methana may give reason to investigate whether feasts were regularly held at religious centers, ${ }^{44}$ but we cannot yet be more precise about the nature of these centers. Nonetheless, this probability should cause excavators and researchers to look again at the remains from identified sanctuary sites for any evidence of feasting that might have been over-
38. Hayden 2001, pp. 28-35; Perodie 2001, pp. 187-188. 39. Hayden 2001, pp. 28-35. 40. Hayden 2001, pp. 29-30. 41. Killen 1998, p. 422; see also Piteros, Olivier, and Melena 1990, pp. 171-184; and Killen 1994.

42. Wright 1994, pp. 69-70. 43. Wright 1994, pp. 63-72. 44. Hamilakis and Konsolaki 2004. 
looked. Places where this would be especially worthwhile are Mycenae, Tiryns, Asine, Amyklai, Epidauros, Delphi, Aigina, and Ayia Triada at Ayios Vassilios.

It remains difficult to identify the reasons for feasting, since, as Clarke's list above (p. 125) indicates, in most instances they are not specific to locales and many of his occasions that might take place in a domestic setting would be equally appropriate at a sanctuary. Sanctuaries are often the locales of special feasts, especially when the deity of the sanctuary is celebrated at a specific time of the year, such as the onset of the new year, the harvest, or some other natural phenomenon marked by celebration. The Linear B texts that record activities, dedications, offerings, and landholdings at shrines and to particular deities are therefore candidates for thinking about ways to specify the occasions of feasting.

Homer is of great value in this matter, as the often-cited festival to Poseidon in book III of the Odyssey illustrates. The epics also provide many specific occasions for feasting. As Sherratt observes in her contribution to this volume, feasting and fighting are the two most frequent activities described in the Iliad and the Odyssey. In her analysis we are confronted with the longstanding problem of whether we can use the epics to understand the Mycenaeans, and if so, how. The crux of this issue rests on whether or not there are sufficient similarities in the structures of Mycenaean and Homeric society to warrant comparison. Comparative study of feasting practice may be a particularly fruitful way of revealing societal structure. In both Mycenaean and Homeric society, feasting is predominantly a male activity in a warrior society. The warrior tradition was established during the Middle Bronze Age and was accentuated during the Early Mycenaean period (Middle Helladic III-Late Helladic II) as aggrandizing elites competed with each other and between different localities. ${ }^{45}$ The symbolism employed by these groups bespeaks their roles as hunters and warriors and is reflected in the iconography shared among the peer-polity palace centers on the mainland and the islands. ${ }^{46}$

Feasting was a central practice in the process of sociopolitical evolution. As Sherratt's comparative examination of Mycenaean and Homeric feasting shows, many of the types of animals sacrificed and eaten, and the practices of cooking and types of equipment employed, are similar, but there remain significant differences, and she concludes that the feasts in Homer's epics primarily describe practices of the Early Iron Age. As she indicates, Homeric feasts are also celebrated on many different occasions, by different social groups, and with different levels of inclusion. In the studies presented here, there is little evidence to suggest such variety, nor can we say much about the different occasions for feasting. Instead, much of what we present is the residue of elite feasting. Nonetheless, progress has been made. Stocker and Davis suggest that at the Palace of Nestor at least two levels of feasting took place, one public and another private and also associated with important ritual practice. In my survey, I argue that the association of the bronze tripod with cooking game such as venison and boar was restricted to elite hunting groups who took their feasting equipment with them to their graves. We hope that future work will focus on refining our understanding of the feast. Some occasions that we might

45. Acheson 1999; Deger-Jalkotzy 1999; Davis and Bennet 1999.

46. Hiller 1999; Kontorli-Papadopoulou 1999; Laffineur 1999b. 
search for are agricultural feasts (planting, harvest), initiation feasts, and funerary feasts, and we are challenged to imagine what kinds of evidence would best demonstrate the occurrence of these feasts and to develop methods for recovering such information.

Borgna grapples with issues of social structure and organization in detail in her comparative study of Minoan and Mycenaean traditions of feasting. It is her contention that feasting, especially its material representation in pottery selection and usage, actively promotes social structure and that archaeologists, through judicious examination of the evidence, can make strong statements about a society and its transformations. By analyzing many contexts on Crete from the Early Bronze Age through the end of the Late Bronze Age, she makes a strong argument that Minoan society was corporate in structure and that more vertical and hierarchical relationships became apparent through the influence of Mycenaean culture. Feasting in Mycenaean society, she argues, was from the beginning focused on individual reciprocity among aggrandizing elites operating in competitive arenas. For this reason she believes that the customs of feasting and drinking associated with Mycenaean funerary practice reflect an exclusive practice among kin and social peers that is different from feasting in Crete. Of particular interest is Borgna's attention to the locales of feasting: interior and exterior, centralized and dispersed. These, she believes, can be recognized through the study of feasting contexts in settlements and in mortuary spaces. More attention to this issue in the different cultural settings of the Aegean and eastern Mediterranean would be valuable, as is demonstrated by Steel's discussion of the location of feasting debris in Cypriot contexts, in building $\mathrm{X}$ at Kalavasos-Ayios Dhimitrios and, especially, in the well deposits near the sanctuary at Kouklia.

Hayden's list of the potential benefits of feasting signifies the dynamic nature of the feast. The broad spectrum of categories covered by the list illustrates the central role that feasting has as a social activity in the formation and maintenance of societies, and thereby points to ways to explore both the evolution of a society as well as the social and cultural dynamics of the relations of power. In the essays that follow, these issues are broached in general terms. In my overview, I explore the ways in which tracing the development of feasting as a formal practice allows us to confront issues in the formation of a Mycenaean cultural identity. The observations I make are amplified by the studies of Cretan and Cypriot feasting practices by Borgna and Steel, who describe and interpret the evidence for "native" feasting practices on these islands before the advent of Mycenaean influence. The contrasts between traditional Minoan and Cypriot practices, on the one hand, and the Mycenaean feast, on the other, are also explored. Minoan feasting expresses the horizontal, group-reinforcing structure of Minoan communities; on Cyprus a more eclectic tradition seems to develop drawing from Anatolia, the Levant, and the Aegean. The authors' identification of Mycenaean elements in Minoan and Cypriot contexts reinforces the notion that the Mycenaean feast was an exclusive custom tied to competition for status and power among elites.

This last point is particularly evident in the study of the pottery, as Borgna argues, and as Steel illustrates in her discussion of the Cypriot attention to the Mycenaean krater. The krater, as a container for wine, 
strongly symbolizes the importance of drinking within these elite groups. It, like the drinking cup, became an icon of the warrior society of the Iron Age, with its codes of honor, as examined by Sherratt in her study of Homeric feasting. Through these studies, the evolving and changing form of feasting appears to be a sensitive gauge of changes in sociopolitical structure, and a useful way to think about continuity through periods of transformation, such as the postpalatial transition to the Iron Age (Late Helladic/Late Minoan IIIC through the Protogeometric period).

In terms of Mycenaean social structure, however, there is much more to explore. None of these papers, for example, considers the role of gender in feasting. The differentiation of social groups within palace society also needs more attention, as Stocker and Davis note in their study of feasting at the Palace of Nestor. ${ }^{47}$ Furthermore, we should address questions about the organization and social divisions within such feasts, of other kinds of feasting, and of feasting not sponsored by the palace, and the methods for doing this are well within our grasp: careful documentation of context, collection of organic remains through sieving and flotation, analysis of soils, and biomolecular investigation for organic residues of comestibles. ${ }^{48}$ In her contribution to the publication of the Sheffield Conference, Bendall pursues some of these issues through a spatial analysis of the areas of feasting and the varying contexts of pottery storage in different areas of the palace. ${ }^{49}$ Both Borgna's and Steel's considerations of "native" Minoan and Cypriot traditions of feasting provide a context for thinking about the feast as an expression of identity and, as Borgna emphasizes, of the structural relations within a society. Here again, issues of power relations and gender are relevant and may be fruitfully explored in further research.

The articles in this volume, therefore, do not represent a comprehensive survey of the practice of feasting in Mycenaean society or the many ways that feasting can be studied to provide insight into the society. They offer, nonetheless, powerful and richly detailed evidence from a variety of sources for Mycenaean feasting. The authors make it clear that feasting was an important activity from the beginning of Mycenaean society until its end and was fundamentally linked to the formation and maintenance of Mycenaean identity. They show how the practice of feasting evolved and, to some extent, how it differed (or how the importance of it differed) from locality to locality and region to region. Although our sources are strongly weighted in favor of Pylos and its territory, feasting seems to have been similarly constructed and practiced at other Mycenaean palace centers as well-certainly Knossos, Mycenae, and Thebes. The contrast of Mycenaean practices with those of cultures with whom the Mycenaeans were in contact confirms the general character of Mycenaean feasting and makes clear the way in which the manipulation of social practices is fundamental to the formation and maintenance of power relations within communities. Material culture in this sense is a sensitive and extremely rich source of information about ancient societies and the specific social practices that define their structure and identity.

In closing, I wish to thank the Institute for Aegean Prehistory for providing funds to bring the participants in the AIA colloquium to Phila-

delphia in 2002. I thank Tracey Cullen for inviting us to submit these

47. See also Isaakidou et al. 2002.

48. Tzedakis and Martlew 1999; McGovern et al. 1999; McGovern 2003.

49. Bendall, forthcoming. 
papers for publication in Hesperia; she has moved this project along with patience and a firm hand. She and her colleagues at the American School of Classical Studies Publications Office have brought a level of professionalism and attention to detail that uphold high standards unusual in this age, though long a tradition at Hesperia. Jeremy Rutter and Brian Hayden, the Hesperia reviewers, have held us to the highest scholarly standards: if these papers succeed in their arguments and have merit in their presentation, it is due in large part to the thoughtful and exceptionally detailed attention they paid to the manuscripts in draft form. We are grateful to all of the above for their help in improving each offering. Finally, to all of the participants, I express my personal thanks for their joining in this undertaking and making their contributions reflect the work of the group.

\section{REFERENCES}

Acheson, P. 1999. "The Role of Force in the Development of Early Mycenaean Polities," in Laffineur 1999a, pp. 97-104.

Bendall, L. M. Forthcoming. "Fit for a King? Hierarchy, Exclusion, Aspiration, and Desire in the Social Structure of Mycenaean Banqueting," in Halstead and Barrett, forthcoming.

Bennet, J. 2001. "Agency and Bureaucracy: Thoughts on the Nature and Extent of Administration in Bronze Age Pylos," in Voutsaki and Killen 2001, pp. 25-37.

Binford, L. 1981. Bones: Ancient Men and Modern Myths, New York.

Branigan, K., ed. 1998. Cemetery and Society in the Aegean Bronze Age (Sheffield Studies in Aegean Archaeology 1), Sheffield.

- 2001. Urbanism in the Aegean Bronze Age (Sheffield Studies in Aegean Archaeology 4), Sheffield.

Chadwick, J. 1958. "The Mycenaean Filing System," BICS 5, pp. 1-5.

-1987. Linear B and Related Scripts (Reading the Past 1), London.

Clarke, M. 2001. "Akha Feasting: An Ethnoarchaeological Perspective," in Dietler and Hayden 2001, pp. 144-167.

Comaroff, J., and J. Comaroff. 1992. Ethnography and the Historical Imagination, Boulder.

Crossland, R. A., and A. Birchall, eds. 1974. Bronze Age Migrations in the Aegean: Archaeological and Linguistic
Problems in Greek Prehistory, Park Ridge, N.J.

Davis, J. L., and J. Bennet. 1999. "Making Mycenaeans: Warfare, Territorial Expansion, and Representations of the Other in the Pylian Kingdom," in Laffineur 1999a, pp. 105-120.

Deger-Jalkotzy, S. 1999. "Military Prowess and Social Status in Mycenaean Greece," in Laffineur 1999a, pp. 121-131.

Dietler, M., and B. Hayden, eds. 2001. Feasts: Archaeological and Etbnographic Perspectives on Food, Politics, and Power, Washington, D.C.

Giddens, A. 1984. The Constitution of Society, Berkeley.

Hägg, R., and N. Marinatos, eds. 1984. The Minoan Thalassocracy: Myth and Reality. Proceedings of the Third International Symposium at the Swedish Institute in Athens (SkrAth 4 $\left.{ }^{\circ}, 32\right)$, Stockholm.

Hägg, R., and G. C. Nordquist, eds. 1990. Celebrations of Death and Divinity in the Bronze Age Argolid. Proceedings of the Sixth International Symposium at the Swedish Institute at Athens (SkrAth 4ㅇ 40), Stockholm.

Halstead, P., and J. C. Barrett, eds. Forthcoming. Food, Cuisine, and Society in Prehistoric Greece (Sheffield Studies in Aegean Archaeology 5), Sheffield.

Halstead, P., and V. Isaakidou. Forthcoming. "Faunal Evidence for Feasting: Burnt Offerings from the Palace of Nestor at Pylos," in Halstead and Barrett, forthcoming. 
Hamilakis, Y., and E. Konsolaki. 2004. "Pigs for the Gods: Burnt Animal Sacrifices as Embodied Rituals at a Mycenaean Sanctuary," OJA 23, pp. 135-151.

Hayden, B. 2001. "Fabulous Feasts: A Prolegomenon to the Importance of Feasting," in Dietler and Hayden 2001, pp. 23-64.

Hiller, S. 1999. "Scenes of Warfare and Combat in the Arts of Aegean Late Bronze Age: Reflections on Typology and Development," in Laffineur 1999a, pp. 319-330.

Hodder, I. 1991. Reading the Past: Current Approaches to Interpretation in Archaeology, New York.

Isaakidou, V., P. Halstead, J. Davis, and S. Stocker. 2002. "Burnt Animal Sacrifice in Late Bronze Age Greece: New Evidence from the Mycenaean 'Palace of Nestor,' Pylos," Antiquity 76, pp. 86-92.

Killen, J. T. 1992. "Observations on the Thebes Sealings," in Mykenaïka. Actes du IX Colloque international sur les textes mycéniens et égéens organisé par le Centre de l'antiquité grecque et romaine de la Fondation bellénique des recherches scientifiques et l'École française d'Athènes (BCH Suppl. 25), ed. J.-P. Olivier, Paris, pp. 365-380.

- 1994. "Thebes Sealings, Knossos Tablets, and Mycenaean State Banquets," BICS 39, pp. 67-84. 1998. "The Pylos Ta Tablets Revisited," pp. 421-422, in F. Rougemont and J.-P. Olivier, eds., "Recherches récentes en épigraphie créto-mycénienne," $B C H 122$, pp. 403-443.

Kontorli-Papadopoulou, L. 1999. "Fresco Fighting-Scenes as Evidence for Warlike Activities in the LBA Aegean," in Laffineur 1999a, pp. 331-339.

Laffineur, R., ed. 1987. Thanatos: Les coutumes funéraires en Égée à l'âge du Bronze. Actes du Colloque de Liège (Aegaeum 1), Liège.

- 1999a. Polemos: Le contexte guerrier en Égée à l'âge du Bronze. Actes de la $7^{e}$ Rencontre égéenne international, Université de Liège (Aegaeum 19), Liège.

- 1999b. "De Mycènes à Homère: Réflexions sur l'iconographie guerrière mycénienne," in Laffineur 1999a, pp. 313-317.

Laffineur, R., and R. Hägg, eds. 2001. Potnia: Deities and Religion in the Aegean Bronze Age. Proceedings of the 8th International Aegean Conference, Göteborg (Aegaeum 22), Liège.

Laffineur, R., and W.-D. Niemeier, eds. 1995. Politeia: Society and State in the Aegean Bronze Age. Proceedings of the 5th International Aegean Conference, Heidelberg (Aegaeum 12), Liège.

Leach, E. 1977. "A View from the Bridge," in Archaeology and Antbropology: Areas of Mutual Interest (BAR Suppl. 19), ed. M. Spriggs, Oxford, pp. 161-176.

Lissarrague, F. 1990. The Aesthetics of the Greek Banquet: Images of Wine and Ritual, trans. A. SzegedyMaszak, Princeton.

McGovern, P. E. 2003. Ancient Wine: The Search for the Origins of Viticulture, Princeton.

McGovern, P. E., D. L. Glusker, R. A. Moreau, A. Nuñez, C. W. Beck, E. Simpson, E. D. Butrym, L. J. Exner, and E. C. Stout. 1999. "A Feast Fit for King Midas," Nature 402, pp. 863-864.

Murray, O., ed. 1990. Sympotica: $A$ Symposium on the Symposion, Oxford.

O'Connor, T. P. 1998. "On the Difficulty of Detecting Seasonal Slaughterings of Sheep," Environmental Archaeology 3, pp. 5-11.

Olivier, J.-P. 1967. Les scribes de Cnossos: Essai de classement des archives d'un palais mycénien (Incunabula graeca 17), Rome.

Orme, B. 1981. Anthropology for Archaeologists: An Introduction, London.

Palaima, T. G. 1984. "Scribal Organization and Palatial Activity," in Shelmerdine and Palaima 1984, pp. 31-39.

- 1987. "Mycenaean Seals and Sealings in Their Economic and Administrative Contexts," in Tractata Mycenaea. Proceedings of the Eighth International Colloquium on Mycenaean Studies, Ohrid, ed. P. H. Ilievski and L. Crepajac, Skopje, pp. 249-266.

-1988. The Scribes of Pylos (Incunabula graeca 87), Rome.
1990. "Origin, Development, Transition, and Transformation: The Purposes and Techniques of Administration in Minoan and Mycenaean Society," in Aegean Seals, Sealings, and Administration. Proceedings of the NEH-Dickson Conference, Austin (Aegaeum 5), ed. T. G. Palaima, Liège, pp. 83-104. . 1996. "Sealings as Links in an Administrative Chain," in Administration in Ancient Societies. Proceedings of Session 218 of the 13th International Congress of Anthropological and Ethnological Sciences, Mexico City, ed. P. Ferioli, E. Fiandra, and G. G. Fissore, Turin, pp. 37-66. 2000a. "Transactional Vocabulary in Linear B Tablet and Sealing Administration," in Administrative Documents in the Aegean and Their Near Eastern Counterparts, ed. M. Perna, Turin, pp. 261-276.

. 2000b. "The Palaeography of Mycenaean Inscribed Sealings from Thebes and Pylos: Their Place within the Mycenaean Administrative System and Their Links with the Extra-Palatial Sphere," in Minoisch-mykenische Glyptik: Stil, Ikonographie, Funktion. V. Internationales Siegel-Symposium, Marburg (CMS Beiheft 6), ed. W. Müller, Berlin, pp. 219-238.

Pappa, M., P. Halstead, K. Kotsakis, and D. Urem-Kotsou. Forthcoming. "Evidence for Large-Scale Feasting at Late Neolithic Makriyalos, N. Greece," in Halstead and Barrett, forthcoming.

Patrik, L. 1985. "Is There an Archaeological Record?" in Advances in Archaeological Method and Theory 8, ed. M. Schiffer, Orlando, pp. 27-62.

Pauketat, T. R., L. S. Kelly, G. F. Fritz, N. H. Lopinot, S. Elias, and E. Hargrave. 2002. "The Residues of Feasting and Public Ritual at Early Cahokia," AmerAnt 67, pp. 257-279.

Perodie, J. R. 2001. "Feasting for Prosperity: A Study of Southern Northwest Coast Feasting," in Dietler and Hayden 2001, pp. 185214.

Piteros, C., J.-P. Olivier, and J. L. Melena. 1990. "Les inscriptions en linéaire $B$ des nodules de Thèbes 
(1982): La fouille, les documents, les possibilités d'interprétation," $B C H 114$, pp. 103-184.

Schmandt-Besserat, D. 2001. "Feasting in the Ancient Near East," in Dietler and Hayden 2001, pp. 391403.

Shanks, M., and C. Tilley. 1987. Reconstructing Archaeology: Theory and Practice, Cambridge.

Shelmerdine, C. W., and T. G. Palaima, eds. 1984. Pylos Comes Alive: Indus- try and Administration in a Mycenaean Palace. Papers of a Symposium, New York.

Speth, J. D. 1983. Bison Kills and Bone Counts: Decision Making by Ancient Hunters, Chicago.

Tzedakis, Y., and H. Martlew, eds. 1999. Minoans and Mycenaeans: Flavours of Their Time, Athens. Ventris, M., and J. Chadwick. 1973. Documents in Mycenaean Greek, 2nd ed., Cambridge.
Voutsaki, S., and J. Killen, eds. 2001. Economy and Politics in the Mycenaean Palace States (Cambridge Philological Society, Suppl. 27), Cambridge.

Wright, J. C. 1994. “The Spatial Configuration of Belief: The Archaeology of Mycenaean Religion," in Placing the Gods: Sanctuaries and Sacred Space in Ancient Greece, ed. S. E. Alcock and R. Osborne, Oxford, pp. 37-78.

\section{James C. Wright}

\section{Bryn Mawr College}

DEPARTMENT OF CLASSICAL AND

NEAR EASTERN ARCHAEOLOGY

BRYN MAWR, PENNSYLVANIA I9OIO-2899

jwright@brynmawr.edu 